\title{
A LIGA ELEITORAL CATÓLICA E A PARTICIPAÇÃO DA IGREJA CATÓLICA NAS ELEIÇÕES DE 1954 PARA A PREFEITURA DE CURITIBA
}

\author{
The Liga Eleitoral Católica and the Church's \\ role in the 1954 mayor elections in Curitiba
}

Renato Augusto Carneiro Junior*

\begin{abstract}
RESUMO
Originalmente desenvolvido como dissertação de mestrado, da qual este artigo é um pequeno extrato, trabalho o tema das relações entre as instituições Estado brasileiro e Igreja Católica, enfocando as atividades da Liga Eleitoral Católica - LEC - nos primeiros anos da década de 1950, em Curitiba. Desenvolvo uma análise de como a Igreja Católica, por meio da LEC, buscava influenciar o resultado das eleições para Prefeitura de Curitiba, em 1954, participando do jogo político, ao indicar de forma clara os candidatos que poderiam ser apoiados pelos católicos. Estabeleço um histórico da formação da LEC no Brasil, em 1932, até sua reformulação na criação da Conferência Nacional dos Bispos do Brasil, em 1952, apresentando suas estratégias de orientação dos eleitores católicos para a manutenção de sua influência junto aos governantes. $\mathrm{Na}$ sequência, é mostrado como foi organizada a campanha eleitoral daquele pleito, seus candidatos, movimentos de alianças e de estabelecimento dos adversários. Apresento, ainda, com base em levantamento em arquivos e jornais de época, a maneira como a Arquidiocese de Curitiba estabeleceu sua Junta Regional da LEC para atender às eleições para prefeito da capital, as primeiras depois do fim do regime do Estado Novo, de Vargas. Por fim, aponto os resultados obtidos pelos diversos partidos, confrontando com as indicações dos editais publicados nos jornais da capital nas vésperas da eleição. Concluindo o artigo, reproduzo o mapa das eleições de 1954 para a Prefeitura Municipal de Curitiba.
\end{abstract}

Palavras-chave: Liga Eleitoral Católica; Curitiba, PR; Ney Braga; eleições 1954.

naense, em Curitiba. Endereço eletrônico: renatocarji@gmail.com. 


\begin{abstract}
Originally developed as a Master's thesis, from which this article is a small extract, I've examined the relations between the Brazilian State and the Catholic Church, especially the Liga Eleitoral Católica (Catholic Election League - LEC) in the early 1950's in Curitiba. I analyzed how the Catholic Church, through the LEC, attempted to influence the mayor elections in Curitiba in 1954, playing the politics game by nominating the candidates who would get the Catholics support. Tracing LEC's history line, from its foundation in Brazil, in 1932, to its reformulation at the Conferência Nacional dos Bispos do Brasil (Brazilian Bishopric National Conference), CNBB, in 1952, I present its orientation strategy for the Catholic voters, in order to maintain a strong influence with the politicians. The 1952 election campaign is also shown in this article, with its candidates, alliances and developments. Based on newspapers and files from the period, I present how the LEC established its regional base to prepare for Curitiba's first mayor elections after the Estado Novo period, in the Vargas Era. The results of the elections are also commented, showing the divergences between them and the indications published by the sponsors of Catholic Church in the city's newspapers on the day before. In conclusion, the 1954 Curitiba mayor election map is reproduced.

Key-words: Liga Eleitoral Católica; Curitiba, PR; Ney Braga; elections 1954.
\end{abstract}

A Liga Eleitoral Católica, LEC, foi criada em 1932, por intermédio do Centro Dom Vital, pelos esforços de Alceu Amoroso Lima, padre Leonel Franca e Dom Sebastião Leme. O Centro foi o núcleo da reação da Igreja Católica no sentido de recristianizar o Brasil. Para concretizar a visão de seus criadores, a instituição aglutinou, ao longo de sua existência, vários intelectuais. Os motivos que levaram à sua formação, no entanto, são bem anteriores a esta data, tendo suas raízes primeiras na ruptura ocorrida entre o Estado brasileiro e a Igreja, por ocasião da Proclamação da República.

Alguns anos mais tarde, em meio à situação de descompasso da Igreja, majoritária na preferência do povo brasileiro, frente à pouca importância atribuída a seus dirigentes, Dom Leme, sendo arcebispo de Olinda, publicava, em 1916, uma Carta Pastoral em que exortava os católicos a assumirem a importância que deveriam ter frente às instituições políticas brasileiras, não se omitindo em face das decisões que afrontassem o espírito cristão. Não era possível que os interesses da maioria católica dos brasileiros fossem conduzidos por uma minoria não católica. 
Entre 1924 e 1926, época em que Arthur Bernardes reformava diversos aspectos da Constituição de 1891, Dom Leme conseguiu o restabelecimento das relações entre o governo brasileiro e a Santa Sé, que, se não haviam sido rompidas de direito, estavam estremecidas desde a Proclamação da República. Não logrou, no entanto, que fossem aprovadas as chamadas "emendas católicas" que introduziriam o ensino religioso nas escolas públicas e reconheceriam o caráter privilegiado da religião católica, visto que professada pela maioria da população brasileira.

Jackson Figueiredo chegou a propor a criação de um partido político católico para defesa dos interesses da Igreja, a exemplo do que já ocorrera no Império, iniciativa logo descartada por Leme, que não queria ver os católicos organizados em uma parte, mas integrados ao todo. Com a morte prematura de Figueiredo, em 1928, aos 37 anos de idade, tal projeto ficou afastado.

Dom Leme, elevado a cardeal do Rio de Janeiro, após a morte do cardeal Arcoverde, em 1930, não pretendia ver os católicos militando em um partido apenas, que se sujeitasse ao jogo político, arriscando-se a perder prestígio e gerando oposições dentro da sociedade. Ele não consentiria na perda de apoio dos católicos que militassem ou preferissem os diversos partidos existentes, já que a intenção do religioso, que se confundia com a da maioria dos bispos brasileiros, era aumentar a influência da Igreja junto ao Estado e à sociedade civil.

Ele achava que os fiéis deveriam integrar-se em todas as agremiações, excetuando-se aquelas de orientação materialista e, portanto, fora dos princípios cristãos, para ser "fermento na massa", ou seja, o elemento de mudança e transformação na sociedade. Desde que os candidatos se comprometessem com um programa mínimo cristão, poderiam e deveriam ser apoiados pelos católicos. A LEC era um grupo de pressão junto à opinião pública, cujo objetivo, segundo seus estatutos, era formar a "consciência política dos católicos independentemente de filiações partidárias e da sua orientação doutrinária-eleitoral"1.

1 CONFERÊNCIA NACIONAL DOS BISPOS DO BRASIL. Proposta de Estatutos da LEC. Rio de Janeiro: CNBB. Mimeografado, 1952. Acredito que tal proposta baseava-se nos antigos estatutos da década de 30, apesar de não ter sido possível comprovar esta afirmação. 
Essa era a ideia de criação da Liga Eleitoral Católica, que iria incorporar-se a ela em todos os momentos de sua existência, com exceção do que se passou no Ceará, onde a Liga constituiu-se em um partido de fato, lançando listas próprias de candidatos, em 1933 e 1934. Em todo o país, a LEC deveria ser suprapartidária e absolutamente neutra na escolha de quais candidatos seriam apoiados pela população católica. Todos os que se comprometessem com o ideário da LEC receberiam igual apoio.

Os grandes princípios defendidos pela LEC nas eleições da Constituinte de 1933 diziam respeito à permanência do nome de Deus no preâmbulo da Constituição; à indissolubilidade do matrimônio e sua validade civil, enquanto celebrado religiosamente; à instrução religiosa nas escolas públicas; à regulamentação da assistência religiosa nos hospitais, prisões e nas forças armadas; à pluralidade e liberdade sindical; à isenção do serviço militar obrigatório para sacerdotes e religiosos; a uma legislação trabalhista inspirada na justiça social cristã; à defesa do direito à propriedade privada; à defesa da ordem social contra atividades subversivas e à supressão de toda e qualquer legislação que contrariasse os princípios da fé católica, como o aborto, divórcio etc.

Além desses, sem tanta ênfase, no entanto, a LEC defendia a instituição de uma política salarial que atendesse com justiça às famílias; um seguro que cobrisse os casos de incapacidade para o trabalho, por doença, acidente ou desemprego; a criação de cooperativas de produtores e consumidores e a representação legislativa de trabalhadores nos conselhos nacionais de economia e trabalho ${ }^{2}$.

Por fim, a LEC punha-se também contra a intervenção do Estado, que deveria se limitar à coordenação dos interesses gerais da sociedade. Opunha-se, mais que tudo, às doutrinas radicais. Foi por esta razão que Alceu Amoroso Lima, secretário-geral, negou a aproximação da LEC com a Ação Integralista Brasileira - AIB, quando Plínio Salgado pleiteava seu reconhecimento como partido católico, propondo-se a defender totalmente o programa e os interesses da Igreja na Câmara Federal. Amoroso Lima não comprometeu a LEC com os integralistas, mesmo reconhecendo pontos em comum entre ambos.

2 FUNDAÇÃO GETÚlIO VARGAS. Dicionário Histórico-Biográfico Brasileiro. 19301983. Rio de Janeiro: Forense Universitária-FINEP, 1984. 
Mantendo-se relativamente neutra quanto aos partidos de centro-direita, apesar de ferrenhamente anticomunista e antidivorcista, a LEC soube canalizar com habilidade os votos dos católicos. O trabalho, pelo relatado em diversas fontes, deve ter sido intenso. As autoridades eclesiásticas insistiam sempre em seus pronunciamentos na identificação da consciência religiosa com o dever cívico do voto, o que demonstra a apatia que a Igreja observava no processo eleitoral. A par disto, fizeram um extenso alistamento - que se traduziu em mais de 60 mil novos eleitores no país, dos quais cinco mil apenas na capital federal ${ }^{3}$. Foi este eleitorado que fez valer a eleição dos candidatos aliados às teses da Igreja.

\section{A reestruturação da LEC na década de 1950}

Depois de extinta pelo Estado Novo, em 1937, e reeditada em 1945, a LEC foi reestruturada junto à Conferência Nacional dos Bispos do Brasil - CNBB, em 17 em outubro de 1952, na própria reunião que instalou a instituição que reuniria todo o episcopado brasileiro. Fruto da experiência de articulação do episcopado junto à realidade nacional, por intermédio da Ação Católica Brasileira - ACB, a CNBB aproveitaria desta a estrutura de departamentos nacionais, que passariam a ser denominados Secretariados Nacionais.

A CNBB criaria, então, alguns secretariados ligados ao Secretariado Geral: o de Educação; o de Ação Social; o do Ensino da Religião; o dos Seminários e Vocações Sacerdotais; o do Apostolado Leigo e a Liga Eleitoral Católica. Na primeira reunião ordinária em Belém, em 1953, criaria também o Secretariado Nacional da Defesa da Fé e Moral ${ }^{4}$.

A LEC ficaria diretamente ligada à Comissão Permanente, sob a presidência do cardeal Dom Carlos Carmelo de Vasconcelos Motta. Logo se tratou de organizar, por meio de representantes leigos dos bispos das capitais,

3 BRANDÃO, B. C. O movimento católico leigo no Brasil. Dissertação (Mestrado em História) - Universidade Federal Fluminense. Niterói, 1975.

4 QUEIROGA, Pe. G. F. CNBB, comunhão e responsabilidade. São Paulo: Paulinas, 1977. p. 175 . 
um documento que seria submetido a todas as dioceses, composto de três partes: um modelo de Estatuto para a criação de diversos níveis de Juntas da Liga, um modelo de Regimento e uma terceira parte, onde se indicavam sugestões para instalação da LEC nas dioceses, divididas em oito pontos.

O primeiro deles era um apelo para a instalação imediata das Juntas Estaduais e Regionais e, tão logo fosse possível, a organização das Juntas Municipais e Locais. O comentário que se segue dizia da conveniência da LEC não atuar apenas nas vésperas das eleições e que cada bispo deveria envidar todos os esforços para "descobrir leigos de confiança" para a missão.

Ressaltavam que "[...] com a antecedência de 2 anos em relação às próximas eleições estaduais, e de 3 anos em relação às próximas eleições federais" seria possível articular os diversos níveis da LEC e dar uma grande passo para a formação cívica dos cristãos, "[...] mas e sobretudo, quando chegarem as eleições, teremos leigos em condições de livrar as batinas da confusão dos pleitos eleitorais." A instalação das Juntas Estaduais ou Regionais, por decreto episcopal, deveria ser comunicada imediatamente ao presidente da Junta Nacional, no Palácio São Joaquim, no Rio de Janeiro.

O segundo ponto dizia respeito à promoção, em caráter permanente, de trabalhos de formação da consciência política dos católicos, mediante o uso dos meios de comunicação e de todos os outros recursos ao seu alcance, inclusive pregações nas missas. O comentário citava a remessa de sugestões por parte do Secretariado Nacional, cujo secretário era Dom Helder Câmara, para serem usadas durante o período da quaresma (entre a quarta-feira de Cinzas e a Páscoa) "[...] tendentes a criar, em todo o Brasil, o clima de repulsa nacional contra o divórcio, cuja adoção em nosso país importaria em grande descrédito para todos nós. [...] Um dos assuntos vitais a encarar, quanto antes, é o problema da expansão comunista no Brasil." Por que na quaresma? Porque tradicionalmente na Igreja Católica é um período de recolhimento, em que o fiel deve ir às missas e se confessar, preparando-se para a Páscoa, estando, talvez, mais predisposto, na visão dos bispos, a receber as mensagens que lhes fortaleceriam a fé.

A terceira sugestão era no sentido de que se intensificasse o alistamento eleitoral, principalmente do eleitorado feminino e dos estudantes de ensino superior e secundário. Os comentários dos bispos que seguiam esta sugestão davam conta de que não se devia pensar que as despesas com a inscrição de eleitores não compensassem, em vista que, depois, muitos 
destes novos eleitores não acatariam as orientações da LEC e que "muito mais cômodo é tirar proveito apenas do alistamento pelos escritórios eleitorais dos diversos Partidos". Este comentário sugere que as despesas com a inscrição de novos eleitores eram consideráveis, uma vez que não eram cobertas pela Justiça Eleitoral, como hoje em parte, e que muitos bispos talvez imaginassem, em vista dos recursos das dioceses, que seria uma esterilização de dinheiro que poderia ser aproveitado de outra forma.

Segue o comentário dizendo que "[...] ao lado de eleitores sem caráter, encontramos, sobretudo no interior, muita gente sincera, capaz de alistar-se e votar por puro espírito da fé." Reconhecia-se, portanto, que muitos talvez não seguissem as indicações da hierarquia. Neste particular, é interessante a notícia da Gazeta do Povo, jornal de Curitiba, com o título "Serão apontados pela Liga Eleitoral Católica os que traíram os compromissos assumidos", dando conta de que muitos políticos não acatavam depois das eleições os compromissos assumidos em campanha, bem como da pouca disciplina dos eleitores em seguir as indicações da LEC.

Por outro lado, perder-se-ia a "[...] extraordinária força moral que representa junto aos Partidos e candidatos a notícia de que a LEC está em pleno alistamento eleitoral." Os bispos bem sabiam do poder de pressão que tinha a arregimentação de eleitores da LEC para obter as garantias que buscavam do poder público. A ameaça de nominar os "traidores" prendia-se à mesma lógica: expor à opinião pública aqueles que não eram capazes de manter sua palavra.

A quarta sugestão era de se criar-se uma Assessoria Técnica para fornecer projetos de lei aos deputados e vereadores a fim de que estes tivessem menos espaço de manobra no atendimento às reivindicações da Igreja. Uma estrutura neste sentido já estava em funcionamento junto à Junta Nacional para articulação com deputados e senadores para colaborar no projeto de Lei Eleitoral e no projeto da Lei de Diretrizes e Bases da Educação, atuando na sequência em projetos voltados à Reforma Agrária e à criação de um Código da Família.

A sugestão seguinte, a quinta, indicava a criação de um fichário político, com registros quanto à atuação, atitudes e declarações dos partidos e seus representantes, para uso na proximidade das eleições. O comentário dos bispos dava conta de que estes dossiês seriam de imediata elaboração por parte da Junta Nacional e que seria desejável a mesma presteza nas capitais, 
em relação aos políticos locais. De fato, alguns trechos deste e de outros documentos sobre a LEC referem-se a publicações especializadas neste sentido da Junta Nacional, as quais, infelizmente, não foi possível encontrar.

A sugestão seguinte era que se mantivesse um contato próximo com as direções dos partidos políticos e das câmaras legislativas para evitar o aparecimento de movimentos contrários aos princípios defendidos pela LEC ou, ao menos, evitar sua propagação. Para tanto, os comentários, apesar de considerarem utópica esta forma de atuação, acreditavam poder contar com os elementos das Assessorias Técnicas para tal tarefa.

Outra sugestão era de se manter um serviço permanente de cobrança dos compromissos assumidos pelos políticos, através, mais uma vez, da Assessoria Técnica. O comentário merece ser transcrito na íntegra:

A publicação oficial da LEC "Partidos e deputados em face ao divórcio" é um primeiro passo nesse terreno e relativo a uma questão que para nós é de vida ou de morte. Se os traidores do compromisso referente à repulsa do divórcio tiverem nas urnas o castigo merecido, haverá, no futuro, maior fidelidade à palavra dada.

A última sugestão era a de se insistir para que os católicos ingressassem nos partidos políticos. O comentário da Comissão Permanente da CNBB que seguia esta sugestão foi:

Claro que se tratará de cada um escolher o partido da própria preferência (desde que esteja em causa um partido compatível com a consciência cristã). Assim agindo, estaremos moralizando a vida política do país e assegurando a presença de fermento cristão na vida íntima de cada partido.

Há, no caso, preconceitos a vencer da parte de homens e sobretudo senhoras que tomaram de asco pelo partidarismo político. Urge esclarecer que a situação política só tenderá a agravar-se, caso continuem ausentes os honestos e capazes.

Parece dispensável recordar que aludimos ao ingresso, nos partidos, de leigos e não de sacerdotes. (grifo do próprio texto) 
Quase às vésperas das eleições de outubro de 1954, a CNBB lançou um manifesto, publicado em Curitiba, no dia 28 de setembro, no jornal Gazeta do Povo, à página 3, próximo às notícias políticas.

Sua introdução descrevia a preocupação dos bispos brasileiros, reunidos em Aparecida do Norte, no dia 11 de setembro daquele ano, com a situação que o país enfrentava com a proximidade do pleito. Eles pretendiam impedir que "forças perversas" - ocultas ou manifestas - confundissem e explorassem a consciência dos católicos, a maioria do eleitorado, para que se "apoderassem da Pátria". O alerta era fundamentalmente feito contra alguns parlamentares, não nomeados, que promoviam campanha pela instituição do divórcio no Brasil.

Os bispos reputavam como uma campanha orquestrada que incluía o desregramento das modas, a obscenidade das revistas, filmes e programas televisionados, das "agências de perversão moral, as casas de tolerância". Para eles, tratava-se de uma campanha antipatriótica.

Chamavam, então, a atenção para as próximas eleições, para que se deixassem de lado interesses sentimentais, partidários ou psicológicos, em favor dos direitos de Deus, da Família e da Pátria. Sempre, nos pronunciamentos e documentos oriundos da Igreja brasileira, Deus e Pátria eram colocados, indissociavelmente, como os deveres primeiros dos católicos. Esta associação dava ao voto uma dupla importância: estar contra a Igreja era estar contra Deus e contra a Pátria. Por ser secreto - portanto, fora do controle direto dos "pastores", daqueles que melhor poderiam orientar o "rebanho" -, o voto dos eleitores em geral e dos católicos em particular poderia ser considerado uma demonstração de "sobrenatural firmeza" ou de "abjeta traição".

Aproveitavam, ainda, para conclamar todos os cidadãos de boa índole numa campanha contra o absenteísmo, que se transformava em um menor número de votos para os candidatos cristãos. Neste ponto, os bispos endossavam a maneira de trabalhar da LEC: poderia ser qualquer candidato, de qualquer partido, à medida que se comprometesse com os princípios defendidos pela LEC desde 1933.

O documento termina pedindo as bênçãos de N. S ${ }^{\text {a }}$. Aparecida para que este "apostólico e paternal apelo" se fizesse repercutir na consciência de todos os brasileiros dignos. 
Como a LEC em seus Estatutos, a Igreja costumava apelar para a consciência dos católicos, pois ela acreditava que, no interior de cada homem, se devia fazer ouvir a voz de Deus, de forma que sua reflexão orientasse sua ação. Esta consciência, longe de ser apenas algo de foro íntimo, era a expressão de uma coletividade cristã, que a Igreja acreditava controlar de alguma maneira, separando seus fiéis para que sequer entrassem na disputa com as demais entidades do mundo secular.

\section{A Prefeitura Municipal de Curitiba entre 1952 e 1954}

O prefeito da capital, por preceito constitucional de 1945, era cargo nomeado pelo governador de cada Estado e pelo presidente da República no caso do Distrito Federal. Por uma emenda à Constituição vigente, tal cargo foi tornado elegível, fato que teve repercussão na Constituição do Estado do Paraná. A Emenda Constitucional nº 1, de 30 de dezembro de 1952, alterava o artigo 127 da Constituição, tornando possível a eleição do prefeito de Curitiba, ressalvado que todas as modificações propostas só entrariam em vigor apenas em $1^{\circ}$ de janeiro de 1954.

O Tribunal Regional Eleitoral do Paraná tomou no início de 1953, então, a iniciativa de marcar a data de 18 de outubro daquele ano para o pleito. Desta forma, o novo prefeito tomaria posse em $1^{\circ}$ de janeiro de 1954. Essa iniciativa diminuía o período do que, nos círculos jurídicos, se chama de vacatio legis, ou seja, de uma lei com data de validade a vigorar no futuro, sem produzir efeitos imediatos.

Entendeu, porém, o Tribunal Superior Eleitoral que o TRE paranaense não poderia marcar as eleições antes da vigência da nova lei. Em resposta ao Recurso $n^{\circ} 45 / 53^{5}$, resolvia, em 17 de agosto de 1953, exigir que tal eleição fosse marcada para após a data de $1^{\circ}$ de janeiro de 1954 . De fato, em 16 de janeiro, o TRE-PR, na $6^{\text {a }}$ Sessão Ordinária, passava a deliberar sobre as eleições para prefeito de $\mathrm{Curitiba}^{6}$. Nesta reunião, debateu-se 1953. p. 129-131.

5 TRIBUNAL SUPERIOR ELEITORAL. Boletim Eleitoral. Rio de Janeiro: novembro de

6 TRIBUNAL REGIONAL ELEITORAL DO PARANÁ. Livro de Atas. Ata da sexta sessão ordinária. Curitiba, 16 de janeiro de 1954. 
a conveniência de fazê-la nas datas de 16 de maio ou de 3 de outubro de 1954, esta última quando se realizaria a escolha de senadores, deputados federais e estaduais.

Contra a primeira proposta, levantou-se o custo que representariam duas eleições em períodos diferentes no mesmo ano, enquanto que contra a coincidência com os demais escrutínios levantava-se a possibilidade de fraudes e anulações de urnas, em virtude de que apenas na capital haveria eleição para a Prefeitura. Postas em votação, foi vencedora a proposta de 3 de outubro, por três votos contra dois, tendo-se abstido o presidente em exercício, Desembargador Eduardo Xavier da Veiga. Tal decisão seria, ainda, contestada por recurso do Partido Trabalhista Nacional, PTN, ao qual o TRE, fazendo repúdio a declarações e ataques de um jornalista e um deputado estadual, negou validade, mandando-o arquivar?

Marcadas as eleições para outubro, intensificaram-se as articulações para se fazer eleger o novo chefe do executivo municipal. Estava em jogo sair em uma posição forte para as eleições para o Governo do Estado, em 1955.

Para a frustrada eleição de 1953 haviam sido lançadas as candidaturas de Tadeu Wallace de Mello e Silva, Roberto Barrozo, João Cid Portugal, Amâncio Moro e Manoel Aranha, que se mantiveram em 1954. Foram ainda candidatos: Alô Guimarães, que se elegeu pelo Partido Social Democrático, PSD, ao Senado na chapa de Moysés Lupion, cedendo vaga para o jornalista Pinheiro Junior, editor do jornal Gazeta do Povo; Paulo Camargo, que se candidatou, vitoriosamente, à Assembleia Legislativa pelo Partido Republicano, e Jofre Cabral e Silva, que também desistiu de ser candidato à Prefeitura ${ }^{8}$.

Ao governador Bento Munhoz da Rocha Netto interessava, naturalmente, fazer o prefeito da capital, o que lhe facilitaria uma candidatura ao Senado nas próximas eleições. José Luís Guerra Rego era o prefeito nomeado por Bento. Com a aproximação do prazo de 180 dias para desincompatibilização, o prefeito pediu sua exoneração com vistas a sua indicação como candidato do Partido Republicano, comandado pelo governador Munhoz da Rocha, que tinha outras preferências.

7 TRIBUNAL REGIONAL ELEITORAL DO PARANÁ. Livro de Atas. Ata da sétima sessão ordinária. Curitiba, 19 de janeiro de 1954.

8 GAZETA DO POVO. Curitiba, 22 de janeiro de 1953. p. 3. Notas Políticas. 
Guerra Rego protagonizou, assim, um acontecimento algo inusitado. Ao deixar a Prefeitura, dirigiu-se à Câmara Municipal para passar ao seu presidente o encargo de substituí-lo. Roberto Barrozo Filho não pôde aceitar, pois assim fazendo inviabilizaria a candidatura de seu pai, o jornalista Roberto Barrozo, dono do jornal O Dia. Toaldo Túlio, vice-presidente da Câmara, foi nomeado Prefeito de Curitiba pelo presidente, sendo-lhe dada posse na tarde de 31 de março, no Paço Municipal.

Sabedor do fato, o governador Bento Munhoz da Rocha nomeou Ernani Santiago de Oliveira prefeito da capital, como lhe facultava a Constituição anteriormente a $1^{\circ}$ de janeiro. Iniciava-se uma batalha jurídica e, durante alguns dias, a cidade teve dois prefeitos. A Presidência da Câmara entrava com pedido de mandado de segurança para garantir a manutenção de Toaldo Túlio, argumentando que, pela Emenda Constitucional, a partir de janeiro de 1954 não caberia nomeação do chefe do executivo municipal por parte do governador. Este, por outro lado, entendia que, se o Presidente da Câmara não assumisse o cargo, não caberia a mais ninguém, senão a ele, nomear o prefeito até a eleição de 3 de outubro.

Por fim, Toaldo Túlio deixou o gabinete do prefeito para Santiago de Oliveira, por solicitação do chefe de polícia Ney Aminthas de Barros Braga, passando a despachar na Presidência da Câmara até que o recurso fosse rejeitado pelo TRE, por entender que a prerrogativa ainda pertencia ao governador até que as eleições marcadas para outubro se sucedessem.

Ao fim e ao cabo, a articulação de Bento Munhoz da Rocha Netto seria vitoriosa. Para fazer de seu cunhado o novo prefeito, Bento retirou o apoio do Partido Republicano a Guerra Rego, promoveu uma coligação com o Partido Social Progressista-PSP e conseguiu o apoio do vereador Myltho Anselmo da Silva, potencial candidato pelo PTB, que, junto com seu grupo político, havia excluído Wallace Tadeu de Mello e Silva do partido, alegando uma aliança deste com o PST antes da convenção partidária do PTB.

Por outro lado, a UDN mantinha a candidatura de Manoel Aranha, sócio e primo de Antonio Braga, pai de Ney, para dividir os votos da oposição, que se não foi mais eficaz, deveu-se ao grande descrédito da agremiação em seguida ao suicídio de Vargas.

A candidatura de Estevam Ribeiro de Souza Neto tirou votos preciosos de Wallace de Mello e Silva, dando a vitória ao candidato oficial. Tal estratégia não desmereceu o empenho de Ney Braga, à medida que, sendo um candidato sem grande expressão própria anterior ao pleito - fora 
o cargo de Chefe de Polícia, nomeado por Bento, onde desempenhou grande atividade nos conflitos de terra no sudoeste do Estado -, foi eleito contra Mello e Silva, o mais forte candidato, que seria muito mais difícil de ser derrotado se tivesse saído com o apoio do PTB. Ney elegeu-se ainda contra o candidato Pinheiro Junior, do PSD, partido forte em nível nacional que, capitaneado por Moysés Lupion no Paraná - ex-governador que se alçaria novamente ao Palácio do Governo, em 1955 -, fez eleger dois senadores e uma bancada de 4 deputados federais e 11 estaduais.

A tabela abaixo fornece uma melhor visualização dos partidos e seus candidatos.

TABELA 1 - Número de deputados e suplentes, por partido, nas eleições de 1954.

\begin{tabular}{c|c|c|c|c}
\hline Partido & $\begin{array}{c}\text { Deputados } \\
\text { Fed. Eleitos }\end{array}$ & $\begin{array}{c}\text { Suplentes } \\
\text { Dep. Federal }\end{array}$ & $\begin{array}{c}\text { Deputados } \\
\text { Est. Eleitos }\end{array}$ & $\begin{array}{c}\text { Suplentes } \\
\text { Dep. Estadual }\end{array}$ \\
\hline PDC & & & 1 & 34 \\
\hline PL $^{*}$ & & & & \\
\hline PR & 2 & 6 & 7 & 45 \\
\hline PSD & 4 & 11 & 10 & 47 \\
\hline PSP & 1 & 6 & 7 & 52 \\
\hline PST/PTN & & & & \\
\hline PTB & 4 & 12 & 11 & 49 \\
\hline UDN & 3 & 3 & 8 & 52 \\
\hline TOTAIS & $\mathbf{1 4}$ & $\mathbf{3 8}$ & $\mathbf{4 4}$ & $\mathbf{2 7 9}$ \\
\hline
\end{tabular}

FONTE: TRE-PR.

* Partidos sem indicação de números por não haverem atingido o coeficiente eleitoral.

Pinheiro Junior, no dia 21, logo após a divulgação do resultado final das eleições, em que conseguiu $17 \%$ dos votos válidos, manifestou-se assim em um longo artigo da Gazeta do Povo, explicando as razões de sua derrota:

[...] Mas as nossas desvantagens não paravam aí. Combatíamos, com justo e compreensível empenho, o Governo, decidido a eleger o seu candidato, e mais a Liga Eleitoral Católica, cujo questionário, por ser impróprio a um candidato ao executivo municipal, não respondemos, e, por fim, todo o clero da cidade e das colônias, que via em nós, na circunstância de não sermos católicos, um grave risco ao futuro da cidade. 
Esta oposição, a do clero, pela maneira por que foi feita e pela qualidade dos que a fizeram - padres estrangeiros em sua grande maioria - será motivo para comentário posterior que dirigiremos, à guiza (sic) de sugestão, aos futuros representantes do Paraná na Câmara Federal, que irão concluir a tarefa de elaborar um novo Código Eleitoral.

Neste passo pretendo tão somente, e cumprindo promessa que fiz a alguns eleitores, desmentir uma das muitas inverdades assoalhadas pelos meus opositores: a de que eu, quando deputado estadual, votara contra a entronização da imagem de Cristo na Assembleia Legislativa.

Não é exato, e desminto a intriga, restabelecendo a verdade, apenas porque esse voto, se verdadeiro, atribuiria a mim um dos sentimentos que julgo indigno do homem: a intolerância. Votei favoravelmente àquela iniciativa, embora afirmando a nenhuma significação que têm para mim as imagens. Aos católicos, todavia, com assento naquele parlamento, cabia o direito, no meu entender, de significar, da forma a mais ampla, a sua fé religiosa. $[\ldots]^{9}$

Apesar da amargura de ter sido derrotado, nota-se no comentário de Pinheiro Junior uma clara indicação de que a Igreja haveria interferido nas chances que ele teria para se eleger prefeito de Curitiba. Não descartando o apoio direto do governador Bento Munhoz da Rocha Netto e todos os esforços da administração municipal de Ernani Santiago de Oliveira, o candidato do PSD creditava à Liga Eleitoral Católica e aos padres, estrangeiros em sua maioria, o fato de os católicos terem lhe recusado seus votos por entendê-lo um "grave risco para o futuro da cidade". Ele dava conta, ainda, de um dos argumentos que teriam sido espalhados por estes padres, uma inverdade sobre sua atuação quando deputado, que lhe reputava um voto contrário à entronização de um crucifixo na Assembleia Legislativa.

Mesmo que a população não aceitasse tal orientação de seus vigários, só o fato de que um candidato derrotado imputasse tamanha importância a eles demonstrava a força que teria a Igreja Católica, ou pelo menos assim imaginariam seus opositores. Como foi visto no caso da campanha contra o espiritismo, promovida na quaresma de 1954, a orientação da Arquidiocese

9 PINHEIRO JUNIOR. Depois do Pleito. Gazeta do Povo, Curitiba, 21 de outubro de 1954. p. 3 . 
de que fossem divulgados os argumentos de interesse da Igreja nos sermões e pregações das missas mostrava que a instituição trabalhava através de seus representantes em todas as oportunidades que se apresentavam para reforçar sua posição frente aos fiéis.

No caso de Pinheiro Junior, nota-se, ao aceitar seu depoimento sobre as causas de sua derrota, que os sacerdotes acabaram por torná-lo alvo de uma campanha de "demonização do adversário", nos moldes dos conceitos apresentados por Girardet, em seu livro Mitos e mitologia politica, no capítulo "O mito da conspiração". Assim agindo, garantiriam que seus seguidores mantivessem-se mais estritamente dentro dos padrões que deles se esperavam, comparecendo à votação e votando nos candidatos referendados pela Liga Eleitoral Católica.

\section{A ação e os resultados da LEC em Curitiba}

Dom Manoel da Silveira D'Elboux, arcebispo de Curitiba entre 1950 e 1970, em consonância com as orientações da CNBB, recém-criada em outubro de 1952, instalou por decreto episcopal a LEC, em 15 de julho de 1953. Para a direção foram designados: Orlando de Oliveira Mello, presidente; José Luiz Demeterco, tesoureiro e João Lacerda Braga, secretário, todos membros da Congregação Mariana ${ }^{10}$.

Tal comissão atuou em palestras, reuniões e encontros em paróquias, associações religiosas e movimentos de leigos. Sua atuação era suprapartidária no apoio dos candidatos que demonstrassem publicamente seu apoio às teses defendidas pela Igreja Católica.

Os trabalhos da Liga não visam apenas [a]o pleito eleitoral. É de seu programa pugnar pela formação cívico-religiosa e moral do povo brasileiro.

Conforme seus estatutos, são finalidades da LEC:

a) a formação da consciência política dos católicos, independente de filiações partidárias e sua orientação doutrinária-eleitoral; 
b) pugnar pelas reivindicações cívicas decorrentes dos princípios cristãos, mediante o exercício de um apostolado permanente ${ }^{11}$.

Um importante componente da estratégia católica era a divulgação, através da imprensa de grande circulação, de editais em que se convocavam os candidatos a cargos eletivos a se manifestarem contra o divórcio, o aborto e demais princípios já defendidos anteriormente nas Constituições de 1934 e 1946. Aqueles que assim o fizessem receberiam o apoio de novos editais com seus nomes e a demonstração de que eram considerados bons candidatos católicos, para que fossem votados pelos demais católicos.

Utilizou-se também da participação em programas de rádio, como a Hora da Ave Maria, sempre às 18 horas, quando, depois das orações, falavam dos princípios defendidos pela LEC. A Igreja manteve também publicações em diversas associações religiosas, paróquias e outros movimentos católicos para a divulgação aos seus filiados de notícias de interesse cristão. Tal proposta veio a se consolidar na publicação do jornal mensal $A$ Voz do Paraná, pela Cúria Metropolitana, a partir de 1956.

A Junta Estadual da LEC no Paraná, para melhor atingir seus objetivos às vésperas das eleições de 1954, marcou uma grande concentração cívica na Praça Tiradentes, no centro de Curitiba, no sábado, dia 25 de setembro daquele ano, para as $20 \mathrm{~h} 15 \mathrm{~min}$. Para tal, fez ampla divulgação nos jornais e emissoras de rádio da capital. O evento, em função de fortes chuvas no horário, acabou não acontecendo, tendo os oradores gravado seus pronunciamentos para transmissão posterior pelas rádios, nos espaços da programação cedidos à LEC.

Na preparação do comício, o jornal $O$ Estado do Paraná publicou, no dia 22 de setembro, uma entrevista com o presidente da LEC, Orlando de Oliveira Mello, médico. É interessante notar como o presidente pensava sua instituição, como encarava o trabalho da Liga e como imagina sua recepção pelos católicos.

Indagado se o povo atenderia aos apelos da Liga, Orlando Mello respondeu incisivamente que sim, não admitindo a possibilidade que as

11 ARQUIDIOCESE DE CURITIBA. Boletim da Federação das Congregações Marianas de Curitiba, ano XII, n. 10, p. 1, outubro de 1953. 
orientações políticas que dava aos católicos não seriam aceitas, dada a pureza de intenções com que trabalhavam. Na prática, se os candidatos apoiados pela LEC para a Prefeitura Municipal de Curitiba tiveram cerca de $39 \%$ dos votos e representavam mais de $90 \%$ do eleitorado, fica claro que nem todos os católicos aceitavam a orientação do órgão especializado da Igreja para questões eleitorais.

Ao ser perguntado se a Liga indicaria candidatos ao povo, Dr. Orlando respondeu que a LEC não imporia nomes, sugerindo, no entanto, uma gama de candidatos, de praticamente todos os partidos que disputavam o pleito, que atenderiam às peculiaridades de cada eleitor católico. Pedia apenas que se atentasse para uma análise das qualidades públicas e dos predicados morais dos candidatos.

Mais adiante, o repórter questionava se uma indicação tão vaga traria os resultados esperados pela LEC. A resposta, um tanto exasperada pela repetição que não se tratava de uma atitude vaga, insistia que deveriam ser observados os interesses maiores (certamente da Pátria e da Igreja, como no manifesto dos bispos da CNBB, de 28/09/1954) e não se limitassem as intenções de voto a parentesco, amizade, simpatia, falsa gratidão ou, mesmo, interesse pessoal ou venda de votos.

Indagado se os católicos teriam obrigação de votar segundo as indicações da LEC, Orlando Mello respondia que a obrigação não era com a LEC, mas com suas convicções religiosas, portanto, uma obrigação com a própria Igreja, sendo desejável que os católicos referendassem os candidatos que se comprometessem publicamente com a LEC, que, por ser um órgão especializado da Igreja, estaria apto a orientar os eleitores.

Outro personagem daquela eleição em Curitiba, em 1954, escreveu suas lembranças do pleito. João Cid de Macedo Portugal, em seu livro de memórias, contava que havia sido candidato do recém-organizado Partido Democrata Cristão, PDC, à Prefeitura de Curitiba. Reputou sua derrota a alguns fatores. $\mathrm{O}$ primeiro deles, à multiplicidade de bons candidatos com força política própria, que teria levado a uma pulverização de votos que favoreceu o candidato do Governo, que pôs sua máquina administrativa em favor de Ney Braga. Este forte apoio, tanto no Governo do Estado quanto na administração municipal, teria se refletido na atuação dos padres que o apoiavam, que passaram a recomendar o nome do candidato do PR/PSP. 
[...] e não fosse a virada do Clero para o lado da candidatura do Ney Braga do PR, o pleito podia ter tomado outro rumo. [...] E diga-se que o meu nome perdeu pontos por falta de dinheiro. Por exemplo, um núcleo forte como Santa Felicidade, que deixou de me dar apoio porque prometi o asfalto, se eleito fosse, enquanto Ney Braga iniciou o asfalto durante a campanha, através do Prefeito Ernani Santiago de Oliveira. Disse ao Padre construir o cinema, se eleito, enquanto o cinema the foi dado desde logo, pelo adversário.

[...] Assim me abandonaram as paróquias de Campo Comprido e outras tantas, uma a uma em troca de favores do governo. Ao que se deduz que o apoio do PSD a mim teria sido decisivo, porque a debandada do Clero em favor do mais forte não teria acontecido $^{12}$.

Depreende-se a influência que tiveram os sacerdotes no pleito. É certo que não se pode aceitar apenas a palavra, talvez ressentida mesmo depois de tanto tempo, de um candidato derrotado, que buscaria justificar retroativamente seu desempenho nas urnas.

Um rápido exame do orçamento do Estado de 1954, porém, revela números que reforçam a tese do Dr. Portugal. De um total de 238 entidades subvencionadas, 69 eram igrejas ou associações católicas, contra apenas 5 de outras religiões e 50 estabelecimentos de ensino católicos, contra 11 outros estabelecimentos de ensino ${ }^{13}$. O jornalista e candidato do PSD, Pinheiro Junior, já havia denunciado em artigo da Gazeta do Povo, em 19 de novembro de 1953, esta prática que pretendia influenciar os votos das igrejas e dos participantes dos times de futebol não só da capital.

Escrevendo sobre esta proposta de orçamento votada pela Assembleia Legislativa para o ano de 1954, Pinheiro Junior destacou o cuidado dos deputados estaduais em:

[...] agradar aos presumíveis ou reais grandes eleitores. Distribuíram, porisso (sic), cinco milhões de cruzeiros a igrejas e clubes de futebol, no pressuposto de que assim conquistariam

12 PORTUGAL, J. C. M. Memórias e reflexões. Curitiba: Lud, 1995. p. 138-139.

13 SECRETARIA DO INTERIOR E JUSTIÇA. Orçamento do Estado do Paraná para o exercicio de 1954. Curitiba: Imprensa Oficial do Estado, 1953. p. 129-141. 
à igreja ou, mais precisamente, ao vigário da paróquia e à mocidade das associações esportivas. O padre é tido pelo político com razão ou sem ela, como um dos mais eficientes cabos eleitorais. Nas colônias estrangeiras, principalmente, a sua opinião é acatada e o conselho rigorosamente seguido. [...] há de se surpreender com a responsabilidade que o Estado assumiu na construção de igrejas em dezenas de municípios e também na manutenção de alguns clubes esportivos até aqui ignorados ${ }^{14}$.

Desta forma, fica patente que não apenas a Igreja-instituição teria influenciado os eleitores na eleição de outubro de 1954, mas também o Governo influenciou decisivamente os sacerdotes para que estes convencessem seus paroquianos a aceitar o candidato do próprio governo, cuja candidatura não tinha nenhum óbice em ser aceita por parte dos católicos, de acordo com as diretrizes da LEC. Também não foi à toa que um dos partidos que teve o maior número de candidatos referendados pela LEC foi justamente o Partido Republicano, ao qual pertencia o governador. As relações eram muito estreitas nesta época entre a Igreja e o Estado, entre o governador e o arcebispo.

Esta foi a maneira pela qual a Igreja teria participado da eleição do major Ney Braga. Não houve, na verdade, um apoio explícito ao candidato em detrimento dos demais, mas uma série de fatos permitiu uma maior aproximação de Ney à Igreja para fazê-lo merecer os votos católicos.

Ney Braga havia sido o chefe de polícia de Bento Munhoz da Rocha Netto e também era viúvo de seu primeiro matrimônio com a irmã do governador. Era de família tradicional da cidade paranaense da Lapa e seus pais católicos fervorosos, como também a família do governador. Um de seus irmãos, João Lacerda Braga, havia sido seminarista, quase chegando à ordenação, e mantendo, após seu afastamento, tal ligação com os movimentos da Igreja que levaram Dom Manoel a indicá-lo como secretário da LEC.

Em seu livro de memórias, Ney Braga escreveu que baseou sua campanha para a Prefeitura no contato pessoal com diversos setores da população curitibana. Sua organização eleitoral compunha-se em pequenos núcleos de cabos eleitorais ligados pessoalmente a ele ou a sua família. Esta

14 PINHEIRO JUNIOR. Dinheiro, eleições e candidatos. Gazeta do Povo. Curitiba, 19/11/1953. p. 3. 
estratégia poderia ser encarada como simpática aos membros da Igreja, uma vez que se apoiava nas famílias e na defesa dos valores cristãos de um pequeno grupo em que a amizade, a gratidão e o relacionamento pessoal eram valorizados. Prova disso foi o apoio da família Mazzarotto, entre tantas de Santa Felicidade, bairro de colonização italiana e profundamente católico ${ }^{15}$.

No final da eleição, a Liga Eleitoral Católica teve eleitos: o prefeito de Curitiba; um dos dois senadores (Moysés Lupion); 10 deputados federais, de 14 indicados (eram 14 vagas); 16 deputados estaduais, de 103 indicados (eram 45 vagas).

TABELA 2 - Candidatos a deputados federal e estadual às eleições de 1954, por partido político, destacando os eleitos, os suplentes e os que foram indicados pela Liga Eleitoral Católica.

\begin{tabular}{c|c|c|c|c|c|cc|c|c|c|c|c}
\hline \multirow{2}{*}{ Partido } & \multicolumn{3}{|c}{ Candidatos a Deputado Federal Candidatos a Deputado Estadual } \\
\cline { 2 - 15 } & $\begin{array}{c}\text { Total } \\
\text { Cand. }\end{array}$ & $\begin{array}{c}\text { Elei- } \\
\text { tos }\end{array}$ & LEC & Supl. & LEC & $\begin{array}{c}\text { Total } \\
\text { LEC }\end{array}$ & $\begin{array}{c}\text { Total } \\
\text { Cand. }\end{array}$ & $\begin{array}{c}\text { Elei- } \\
\text { tos }\end{array}$ & LEC & Supl. & LEC & $\begin{array}{c}\text { Total } \\
\text { LEC }\end{array}$ \\
\hline PDC & & & & & & & 35 & 1 & & 34 & 9 & 9 \\
\hline PL $^{*}$ & & & & & & & & & & & $4^{* *}$ & 4 \\
\hline PR & 8 & 2 & 2 & 6 & 4 & 6 & 52 & 7 & 5 & 45 & 17 & 22 \\
\hline PSD & 15 & 4 & 2 & 11 & 3 & 5 & 57 & 10 & 2 & 47 & 17 & 19 \\
\hline PSP & 7 & 1 & 1 & 6 & - & 1 & 59 & 7 & 1 & 52 & 13 & 14 \\
\hline PST/ & & & & & & & & & & & $1 *$ & 1 \\
PTN & & & & & & & & & & & 14 \\
\hline PTB & 16 & 4 & 2 & 12 & 1 & 3 & 60 & 11 & 2 & 49 & 8 & 10 \\
\hline UDN & 6 & 3 & 3 & 3 & 2 & 5 & 60 & 8 & 5 & 52 & 19 & 24 \\
\hline TOTAL & $\mathbf{5 2}$ & $\mathbf{1 4}$ & $\mathbf{1 0}$ & $\mathbf{3 8}$ & $\mathbf{1 0}$ & $\mathbf{2 0}$ & $\mathbf{3 2 3}$ & $\mathbf{4 4}$ & $\mathbf{1 5}$ & $\mathbf{2 7 9}$ & $\mathbf{8 8}$ & $\mathbf{1 0 3}$ \\
\hline
\end{tabular}

FONTES: jornal O Dia, de 02/10/1954 e Relação de Candidatos do TRE-PR

* O PL e o PST/PTN não conseguiram o coeficiente eleitoral mínimo, não tendo seus resultados divulgados pelo TRE-PR.

** O PDC não ofereceu candidatos para a Câmara Federal nesta eleição.

*** Esses candidatos são nominados apenas pela relação de apoiados pela LEC.

15 BRAGA, N. Tradição e mudança na vida política. Curitiba: Ed. do autor, 1996. p. 61. Esta família já havia dado à Igreja o bispo de Ponta Grossa, Dom Antonio Mazzarotto e, mais tarde, seu irmão seria sagrado bispo auxiliar de Curitiba, Dom Jerônimo. Nesta ocasião, em 1957, somavam ainda mais dois padres (outro irmão dos bispos e um sobrinho), um seminarista, três irmãs freiras e uma sobrinha, também irmã de caridade. Dona Amália, matriarca da família, receberia a Comenda Pro Ecclesia et Pontifice, em 1955, por sua veneração religiosa e dedicação à Igreja, como se vê em FEDALTO, P. A Arquidiocese de Curitiba na sua história. Curitiba: s/ed., 1958. p. 353. 
A relação dos candidatos às eleições de outubro de 1954 apoiados pela LEC, quando confrontada com a relação dos deputados e suplentes divulgada pelo Tribunal Regional Eleitoral do Paraná, oferece alguns elementos para análise da situação político-partidária.

De acordo com a tabela, pode-se constatar que os partidos que mais ofereceram candidatos e que, portanto, teriam uma maior inserção na sociedade foram o PSD e o PTB. Acabaram seguidos pelo PR, que, sendo o partido do governador, não chegou a atrair um grande número de interessados à Câmara Federal, apesar de fazê-lo à Assembleia Legislativa. O mesmo se passou com o PSP e a UDN. O PDC tinha uma pequena estrutura, que lhe permitiu apenas lançar candidatos para o legislativo estadual, elegendo um só nome. O PL e a coligação entre o PST/PTN, liderada pelo jornalista Roberto Barrozo, do jornal O Dia, tiveram pequena votação, não chegando a completar o coeficiente eleitoral mínimo, razão pela qual seus candidatos não tiveram divulgados seus votos pelo TRE-PR.

Pode-se perceber também que os partidos aliados tiveram a maior porcentagem de candidatos apoiados pela LEC. O PR teve mais de $47 \%$ de seus candidatos subscrevendo as teses da Liga. A UDN teve $44 \%$ e o PSP, $23 \%$.

No PDC, dentre os 35 candidatos que se apresentaram, 9 tiveram seus nomes divulgados pelo edital da LEC. O interessante é que o único que se elegeu deputado estadual não estava entre eles. Isso mostra, por um lado, que o Partido da Democracia Cristã não tinha o respaldo da Igreja no Paraná - e, no Brasil, a situação era menos confortável ainda -, como seus congêneres na Europa. Por outro, mostra que, proporcionalmente, poucos de seus candidatos (26\%) se preocuparam em obter apoio dos católicos por intermédio da Liga Eleitoral.

$\mathrm{O} P S D$, partido tradicionalmente ligado às oligarquias, tinha um terço de seus candidatos apoiados pela LEC, enquanto o PTB, com suas raízes mais populares, no sindicalismo de Vargas, contava com apenas $17 \%$ de candidatos apoiados pelos católicos. Esses números fazem pensar que a estrutura de apoio ao governo procurou mais que os outros partidos o endosso da LEC aos seus candidatos.

Com toda esta estratégia de articulação, Bento Munhoz da Rocha Netto logrou fazer uma grande base nos legislativos federal e estadual. Ao somarem-se os eleitos pelo PR, PSP e UDN, tem-se uma proporção de 79\% 
dos deputados federais como aliados do governo, enquanto que na Assembleia estadual este montante chegaria a 50\%, sem se considerar o PTB, que entrou dividido na disputa, com considerável parte de sua bancada ao lado da situação governista.

O desempenho dos candidatos apoiados pela LEC para o executivo de Curitiba foi igualmente importante. Ney Braga (PSP/PR), João Cid Portugal (PDC) e Manoel Aranha (UDN) fizeram um total de 23.995 votos, num universo de 64.210 votantes, ou seja, quase $38 \%$ dos votos para prefeito municipal. Com a votação individual de 18.327 votos, Ney Braga elegeu-se com $29 \%$ dos votos válidos do eleitorado curitibano.

A LEC não foi tão eficiente, no entanto, no que diz respeito ao absenteísmo: naquela eleição, 33.030 votantes inscritos no Tribunal Eleitoral, cerca de $34 \%$ dos eleitores, deixaram de comparecer às urnas. O TRE-PR registrava 97.240 eleitores habilitados ao voto em 4 de setembro de $1954^{16}$. Este fato pode ser creditado à chuva miúda e fria que se abateu sobre a capital do Paraná no domingo, 3 de outubro de 1954. Mas, de qualquer forma, um terço dos eleitores não atendeu ao chamamento da Liga Eleitoral Católica para que não se furtassem ao dever do voto.

\section{Conclusão}

Apoiada na concepção de uma cristandade universal, que remonta à Idade Média, a Igreja Católica acreditava no seu papel de condutora dos destinos espirituais das populações dos países em que ela se inseria. Via-se igualmente responsável pela moral e a ética destas mesmas sociedades, pois a todo um conjunto de crenças espirituais corresponderia uma prática social. Sua atuação no campo social, no entanto, fundamentava-se na assistência que pudesse dar ou fizesse dar aos menos amparados pela providência divina.

A Igreja Católica da década de 1950 no Brasil era aquela em que grupos defendiam sua visão de mundo consoante com sua atuação enquanto pastores dos fiéis católicos. A Igreja no Paraná firmou, conscientemente ou

16 TRIBUNAL REGIONAL ELEITORAL DO PARANÁ. Mapa Geral das Eleições realizadas em 3 de outubro de 1954. Curitiba. 
não, uma estratégia política à semelhança daquela empreendida, ainda na década de 1930, pelo Cardeal Leme, de influência junto aos governantes, políticos, intelectuais e às camadas médias urbanas.

Não se tratou, no entanto, de um isolamento das questões sociais, uma vez que ainda assim tal posição representava um avanço em relação à prática anterior. Era, de toda a forma, condizente com o modelo de modernização empreendido pela sociedade brasileira, tanto no nível federal quanto no nível estadual. As práticas de Ney Braga e do seu grupo político nos governos que se seguiram revelaram a adoção de muitas posições defendidas pela cúpula da Igreja, traduzindo-se em políticas de governo voltadas ao atendimento dos problemas sociais das populações ao seu encargo. Desta forma, é possível se falar na influência da Igreja Católica na condução dos destinos da sociedade brasileira.

Os resultados das eleições para a Prefeitura de Curitiba, Assembleia Legislativa, Câmara e Senado Federal, bem como o grande número de abstenções em 1954, mostram, no entanto, que a hierarquia da Igreja supunha uma força maior do que a que se demonstrou. Por outro lado, as notícias de que ela denunciaria os políticos que, tendo se comprometido, não cumprissem com seus deveres para com os princípios da LEC, mostra que não havia uma tão grande preocupação com os possíveis apoios que a Igreja pudesse gerar. Não que se desprezasse esse apoio, mas talvez ele não tenha sido tão decisivo.

De qualquer forma, é importante notar que, com esta prática, a Igreja Católica se propôs a atacar dois grandes problemas sentidos na época: o absenteísmo nas eleições e o voto fisiológico, por motivos menores. Mesmo que baseasse sua campanha na defesa de interesses de um setor da sociedade - o dos católicos, que, ao ver da hierarquia, tratava-se da ampla maioria da população -, seu trabalho visava a uma conscientização maior do eleitorado, com a valorização do papel dos eleitores, chamando-os a defender a lisura do processo, ao não permitir que candidatos considerados não adequados se elegessem, prejudicando assim a qualidade dos membros do poderes legislativo e executivo frente ao trabalho que deveriam empreender pela melhoria das condições de vida da sociedade brasileira, dentro dos preceitos cristãos. 


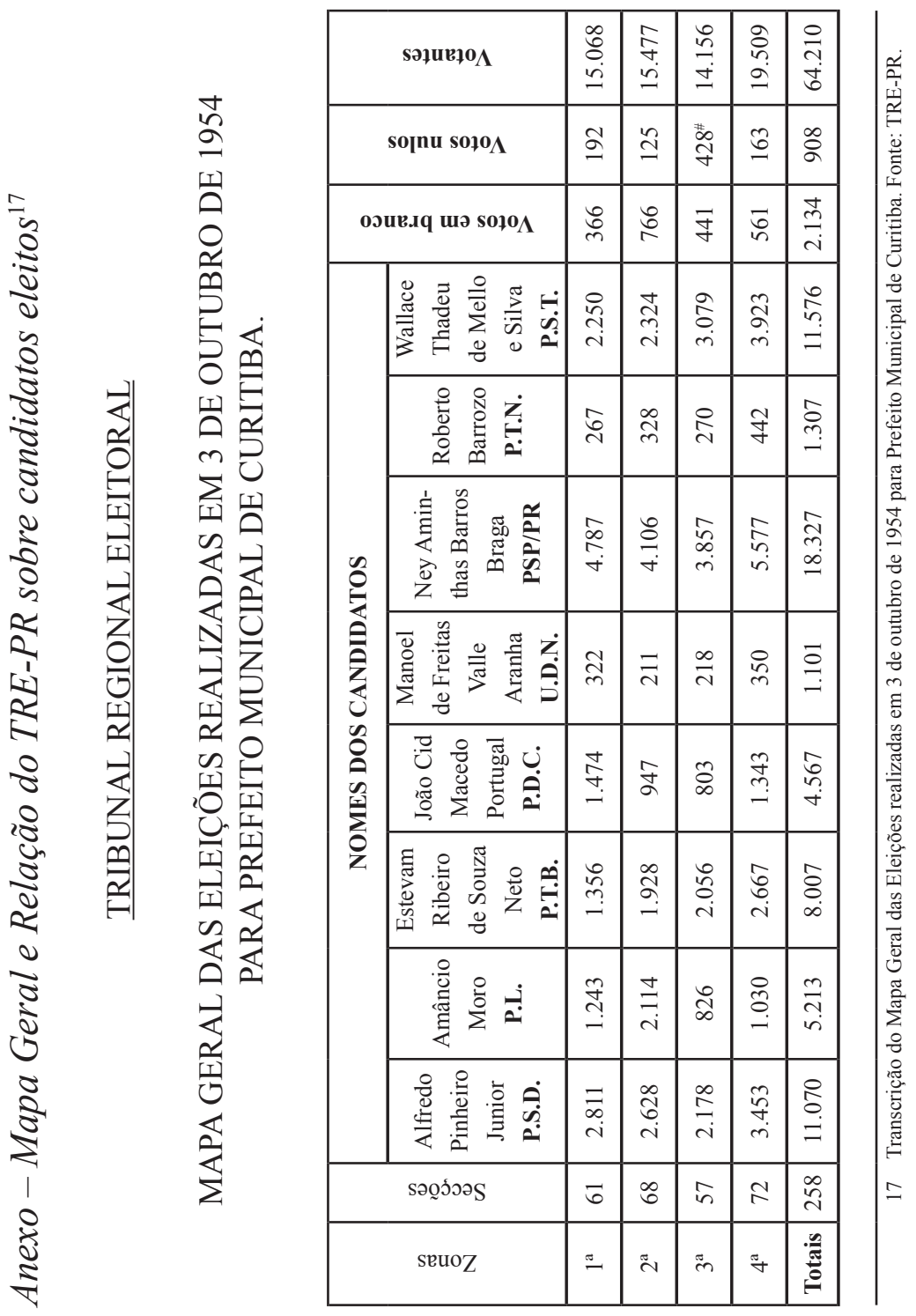




\section{RESUMO ESTATÍSTICO}

Soma dos votos aos candidatos acima...............61.168

Votos em branco

.2 .134

Soma dos votos válidos 63.302

Votos nulos .908

Total de votantes 64.210

Abstenção verificada $\underline{33.030}$

Eleitorado das 4 zonas em 04.09.1954 97.240

$1^{\mathrm{a}}$ zona 22.211

$2^{\mathrm{a}}$ zona 24.080

$3^{\mathrm{a}}$ zona 23.181

$4^{\mathrm{a}}$ zona $\underline{27.768}$

Total 97.240

(Compilado pelos quadros fornecidos pelas Juntas Apuradoras respectivas)

Curitiba, (ilegível) julho de 1955

Organizado (ilegível)

Nota do autor: O grande número de votos nulos nesta zona eleitoral deve-se à anulação de uma urna, da $13^{\mathrm{a}}$ seção, por votos em trânsito fora da conformidade com a Lei Eleitoral. Esta seção funcionava no Clube Curitibano, na rua Barão do Rio Branco, centro de Curitiba.

Recebido em dezembro de 2010. Aprovado em fevereiro de 2011. 